\title{
Zastosowanie biometeorologicznej klasyfikacji warunków pogodowych w rekreacji i turystyce w Polsce środkowo-zachodniej
}

\author{
Biometeorological classification of weather conditions for tourism \\ and recreation in central-western Poland
}

\author{
AGNIESZKA MĄKOSZA \\ Katedra Meteorologii i Kształtowania Terenów Zieleni, \\ Zachodniopomorski Uniwersytet Technologiczny w Szczecinie, \\ 71-459 Szczecin, Papieża Pawła VI 3; agnieszka.makosza@zut.edu.pl
}

Zarys treści. Praca dotyczy oceny warunków pogodowych na obszarze Polski środkowo-zachodniej do celów turystyczno-rekreacyjnych przy wykorzystaniu biotermiczno-meteorologicznej klasyfikacji warunków pogodowych składającej się z typów, podtypów i klas pogody. Obliczenia przeprowadzono na podstawie danych meteorologicznych z południowego terminu pomiarowego (12.00 UTC) z okresu 1971-2006. W rozpatrywanych latach wystąpiło od 112 (Gorzów Wlkp.) do 130 (Słubice, Koło) różnych rodzajów pogody będących kombinacją jej typów, podtypów i klas. Ze wszystkich wyznaczonych typów pogody, 20 najczęściej występujących decydowało o warunkach pogodowych w ponad $80 \%$ dni w roku. Największą różnorodnością warunków pogodowych odznacza się lato, a najmniejszą zima. W pracy obliczono także wskaźnik WEI(avg), na podstawie którego wydzielono okresy najbardziej odpowiednie do kąpieli słonecznych i powietrznych oraz do rekreacji związanej z umiarkowaną i intensywną aktywnością.

Słowa kluczowe: bioklimat, Polska środkowo-zachodnia, typy pogody, warunki biotermiczne, wskaźnik oceny pogody.

\section{Wstęp}

Poszczególne elementy środowiska, takie jak wody, lasy czy rzeźba terenu stanowią podstawę walorów turystycznych i wypoczynkowych. Wśród zasobów naturalnych determinujących rozwój turystyki wymienia się także warunki klimatyczne, wpływające m.in. na długość sezonu turystycznego czy sezonowy rozkład ruchu turystycznego (Koźmiński i inni, 2015). Według bioklimatycznej regionalizacji, opracowanej przez T. Kozłowską-Szczęsną i innych (1977) 
obszar Polski środków-zachodniej zaliczany jest do IV regionu bioklimatycznego (Region Centralny) o słabych bodźcach, co można uznać za element korzystny, bowiem występujące tu sytuacje pogodowe (w porównaniu np. z obszarami nadmorskimi) nie obciążają układu termoregulacyjnego organizmu i tym samym nie stanowią większych ograniczeń dla turystyki i rekreacji.

Ocena warunków pogodowych, na potrzeby turystyki i rekreacji powinna składać się z analizy zespołu elementów meteorologicznych i obejmować trzy rodzaje informacji odnoszących się do oceny warunków wizualnych, fizycznego stanu atmosfery i warunków biotermicznych, ważnych dla osób przebywających, odpoczywających czy też pracujących na otwartym powietrzu (Matzarakis, 2001; Freitas, 2001, 2003).

Kompleksowe oddziaływanie klimatu na organizm człowieka - jego samopoczucie, możliwość regeneracji sił, najpełniej określają różne klasyfikacje pogody opisywane poprzez częstość i następstwo różnych warunków pogodowych (Dubicka i Sikora, 2005). Istniejące klasyfikacje pogody uwzględniające wpływ pogody na człowieka obejmują dwie główne grupy, odnoszące się do odziaływania układów barycznych na człowieka (klasyfikacje biosynoptyczne) i analizujące wpływ zespołu elementów meteorologicznych (typologie) - K. Błażejczyk i A. Kunert (2011). Do bioklimatycznej typologii pogody, uwzględniającej kategorie informacji niezbędne dla rekreacji i turystyki proponowane przez C.R. de Freitasa (2001, 2003), służy oparta na bilansie cieplnym człowieka, biotermiczno-meteorologiczna klasyfikacja pogody opracowana przez K. Błażejczyka (2002, 2004, 2005). Klasyfikacja ta znalazła zastosowanie w wielu opracowaniach dotyczących różnych obszarów Polski między innymi Warszawy (Błażejczyk, 2004), Wrocławia (Dubicka i Sikora, 2005; Sikora, 2008), jak również strefy wybrzeża (Koźmiński i Michalska, 2008), obszarów górskich i podgórskich (Miszuk, 2006, 2008; Wereski, 2012) czy nizinnych (Koźmiński i inni, 2007; Mąkosza, 2007; Koźmiński i Michalska, 2011).

Celem niniejszego opracowania jest określenie częstości występowania typów, podtypów i klas pogody oraz ocena warunków pogodowych, na podstawie biotermiczo-meteorologicznej klasyfikacji pogody, przydatnych do turystyki i wypoczynku w Polsce środkowo-zachodniej.

\section{Materiał i metody}

Analiza dotyczy obszaru Polski środkowo-zachodniej (ryc. 1), który według regionalizacji fizycznogeograficznej opracowanej przez J. Kondrackiego (2002), obejmuje Pojezierze Lubuskie, Pojezierze Wielkopolskie, Pradolinę Warciańsko-Odrzańską, Wzniesienia Zielonogórskie i Pojezierze Leszczyńskie.

Podstawą opracowania było zastosowanie biotermiczno-meteorologicznej klasyfikacji pogody opracowanej przez K. Błażejczyka (2004, 2005), stosowanej przy ocenie warunków pogodowych do szeroko rozumianych celów turystyczno- 
-rekreacyjnych. Schemat przywołanej klasyfikacji zawiera tabela 1. Do określenia typów i podtypów pogody wykorzystano codzienne terminowe (12.00 UTC) wartości elementów meteorologicznych z lat 1971-2006 (temperatura powietrza, ${ }^{\circ} \mathrm{C}$, wilgotność względna powietrza, \%, zachmurzenie, \%, prędkość wiatru, $\mathrm{m} \cdot \mathrm{s}^{-1}$ ), pochodzace $\mathrm{z}$ zasobów państwowej sieci obserwacyjno-pomiarowej IMGW-PIB dla stacji: Gorzów Wlkp., Słubice, Zielona Góra, Leszno, Poznań, Koło, Toruń (ryc. 1). Klasy pogody zidentyfikowano, zgodnie z metodyką, na podstawie dobowej amplitudy temperatury powietrza i dobowych sumy opadów atmosferycznych. Ze względu na fakt, że opracowanie obejmuje obszar niewykorzystywany do celów turystyki narciarskiej oraz występująca tutaj średnia liczba dni z pokrywą śnieżną jest bardzo mała, element ten został pominięty. W związku z tym w zapisie ostatnia cyfra zawsze będzie wynosić x (dzień bez śniegu) - np. 3_3H1_10x.
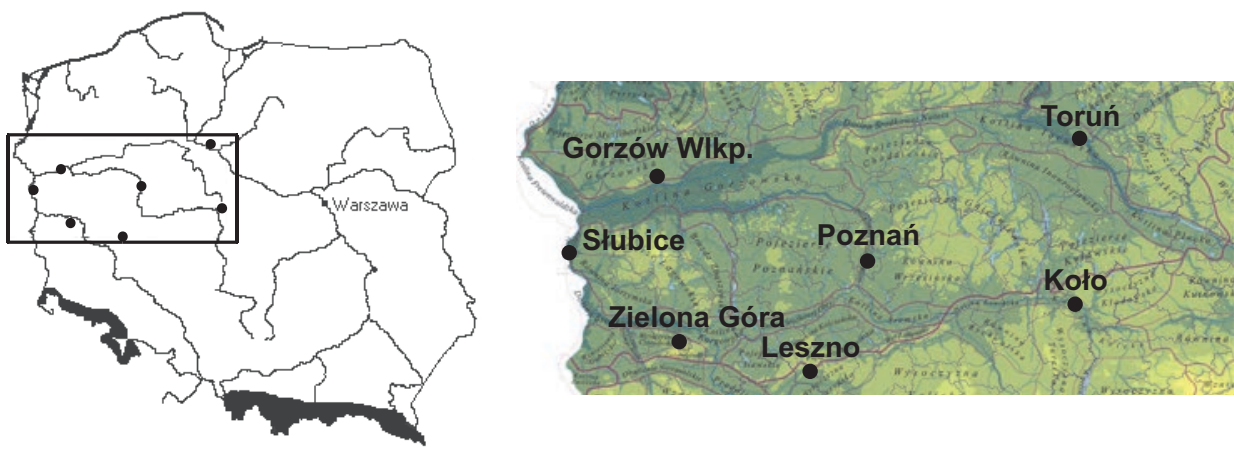

Ryc. 1. Rozmieszczenie stacji meteorologicznych na obszarze Polski środkowo-zachodniej Location of meteorological stations in central-western Poland Opracowanie własne na podstawie mapy regionalizacji fizycznogeograficznej Polski (Kondracki, 2002).

Author's own elaboration on the basis of the physical-geographical regionalisation map of Poland (Kondracki, 2002).

Wszystkie obliczenia wykonano przy wykorzystaniu programu BioKlima 2.6. W kolejnym etapie pracy, na podstawie typów, podtypów i klas pogody, dokonano waloryzacji warunków bioklimatycznych do rekreacji i turystyki na analizowanym terenie w latach 1971-2006 dla wybranych formy rekreacji i wypoczynku (kąpiele słoneczne (SB), kąpiele powietrzne (AB), łagodna rekreacja ruchowa (MR), intensywna rekreacja ruchowa (AR). Do tego celu wykorzystano bezwymiarowy wskaźnik oceny pogody $\left(W E I_{\text {avg }}\right)$ którego zakres zamieszczono w tabeli 2. 
Tabela 1. Schemat klasyfikacji biotermiczno-meteorologicznej

Scheme of digital description of bio-thermal- and -meteorological weather classification

\begin{tabular}{|c|c|c|c|}
\hline & $\begin{array}{l}\text { Charakterystyka pogody } \\
\text { Weather characteristic }\end{array}$ & $\begin{array}{c}\text { Wskaźnik } \\
\text { (charakterystyka opisowa pogody) } \\
\text { Indicator (descriptive } \\
\text { characteristics of weather) }\end{array}$ & $\begin{array}{c}\text { Miejsce } \\
\text { zapisu } \\
\text { Digit place }\end{array}$ \\
\hline 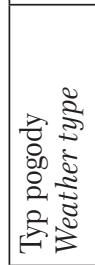 & $\begin{array}{l}\text { odczucia cieplne } \\
\text { thermal sensations }\end{array}$ & $\begin{array}{l}\text {-3 (bardzo zimno / very cold) } \\
-2 \text { (zimno / cold) } \\
-1 \text { (chłodno / cool) } \\
0 \text { (komfortowo / comfort) } \\
1 \text { (ciepło / warm) } \\
2 \text { (goracco / hot) } \\
3 \text { (bardzo gorąco / very hot) }\end{array}$ & 1 \\
\hline & $\begin{array}{l}\text { bodźce radiacyjne } \\
\text { radiation stimuli }\end{array}$ & $\begin{array}{l}1 \text { (słabe / weak) } \\
2 \text { (umiarkowane / moderate) } \\
3 \text { (silne / strong) }\end{array}$ & 2 \\
\hline 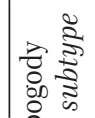 & $\begin{array}{l}\text { stres termofizjologiczny } \\
\text { physiological strain }\end{array}$ & $\begin{array}{l}\mathrm{C} \text { (stres zimna / cold stres) } \\
\mathrm{T} \text { (termoneutralnie / thermoneutral) } \\
\mathrm{H} \text { (stres gorąca / hot stres) }\end{array}$ & 3 \\
\hline 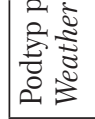 & $\begin{array}{l}\text { wskaźnik parności } \\
\text { sultriness intensity }\end{array}$ & $\begin{array}{l}0 \text { (brak / non sultry) } \\
1 \text { (umiarkowana / moderate) } \\
2 \text { (duża / great) }\end{array}$ & 4 \\
\hline \multirow{3}{*}{ 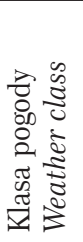 } & $\begin{array}{l}\text { dobowe kontrasty termiczne } \\
\text { daily thermal contrasts }\end{array}$ & $\begin{array}{l}1 \text { (duże / significant) } \\
0 \text { (małe / insignificant) }\end{array}$ & 5 \\
\hline & $\begin{array}{l}\text { opady } \\
\text { precipitation }\end{array}$ & $\begin{array}{l}1 \text { (dzień z opadem / rainy day }) \\
0 \text { (dzień bez opadu / no rain })\end{array}$ & 6 \\
\hline & $\begin{array}{l}\text { pokrywa śnieżna } \\
\text { snow cover }\end{array}$ & $\begin{array}{l}1 \text { (dzień ze śniegiem / snowy day) } \\
0 \text { (dzień bez śniegu / no snow) }\end{array}$ & 7 \\
\hline
\end{tabular}

Źródło / Source: Błażejczyk (2005).

Tabela 2. Skala oceny przydatności warunków pogodowych na podstawie wskaźnika $W E I_{\text {avg }}$ Assessment scale of weather conditions suitability as based on the $W E I_{\text {avg }}$ index

\begin{tabular}{|c|l|}
\hline$W_{\text {(avg) }}$ & \multicolumn{1}{|c|}{ Pogoda / Weather } \\
\hline$<0,5$ & niekorzystna / unfavourable \\
$0,5-1,19$ & umiarkowanie korzystna / moderate favourable \\
$1,2-1,99$ & korzystna / favourable \\
$\geq 2,0$ & bardzo korzystna / very favourable \\
\hline
\end{tabular}

Źródło / Source: Błażejczyk (2005). 


\section{Wyniki}

W analizowanym wieloleciu 1971-2006 w Polsce środkowo-zachodniej średnio rocznie wystąpiło od 112 (Gorzów Wlkp.) do 130 (Słubice, Koło) różnych rodzajów warunków pogodowych będących kombinacją jej typów, podtypów i klas. Uzyskane wartości są nieco większe niż obliczone przez K. Błażejczyka (2004, 2005) w odniesieniu do Warszawy w okresie 1994-2001, czy przez M. Dubicką i S. Sikorę (2005) dla Wrocławia w okresie 1981-2000 - odpowiednio 95 i 97. Pomimo tak dużej różnorodności warunków pogodowych w Polsce środkowo-zachodniej, stwierdzono, że od 18 (Poznań, Koło, Zielona Góra) do 21 (Słubice) jej kombinacji stanowi w sumie 80\% wszystkich występujących przypadków w ciągu roku, natomiast pierwszych 6-7 decyduje w 50\% o układzie warunków pogodowych (tab. 3). Zbliżoną zależność występowania warunków pogodowych uzyskali także w swoich pracach wspomniani wcześniej Błażejczyk (2004, 2005) oraz Dubicka i Sikora (2005).

Jak wynika z danych przedstawionych w tabeli 3, najczęściej w ciągu roku, od 18,8\% w Słubicach do 24,6\% w Zielonej Górze, występował układ warunków pogodowych charakterystyczny dla typu pogody zimnej ze słabymi bodźcami radiacyjnymi, podczas której panował stres zimna i brak było uczucia parności, z małymi dobowymi kontrastami termicznymi, częściej bez opadu atmosferycznego niż z opadem (-2_1C0_00x i -2_1C0_01x). Jedynie w Kole stwierdzono nieco częstsze występowanie typu pogody chłodnej $\left(-1 \_1 \mathrm{C} 0 \_00 \mathrm{x}-9,1 \%\right)$ niż zimnej $\left(-2 \_1 \mathrm{C} 0 \_00 \mathrm{x}\right.$ - 8,3\%), niemniej z takim samym układem podtypów i klas. Typ chłodnej pogody wraz podtypami i klasami tworzy w środkowo-zachodniej Polsce kolejny co do częstości występowania układ warunków pogodowych w ciągu roku. Określone warunki pogodowe w typie pogody chłodnej cechują się przede wszystkim słabymi bodźcami radiacyjnymi, stresem zimna i brakiem uczucia parności. Różnice natomiast uwidaczniają się w klasach i możemy wyróżnić tu np. pogodę chłodną z małymi kontrastami termicznymi i brakiem opadów (-1_1C0_00x), małymi kontrastami termicznymi i opadami $\left(-1 \_1 C 0 \_01 x\right)$ lub dużymi kontrastami termicznymi i brakiem opadów $\left(-1 \_1 \mathrm{C} 0 \_10 \mathrm{x}\right)$ albo też dużymi kontrastami termicznymi i opadami (-1_1C0_11x), która to nieco częściej pojawia się w Lesznie i Zielonej Górze. Wśród określonych za pomocą biotermiczno-meteorologicznej klasyfikacji warunków pogodowych na analizowanym obszarze, występujących z minimum 5\% częstością w roku w latach 1971-2006, znalazł się też typ pogody ciepłej z umiarkowanymi bodźcami radiacyjnymi, brakiem stresu termofizjologicznego, brakiem parności, dużymi kontrastami termicznymi i brakiem opadów (1_2T0_10x) oraz typ pogody komfortowej również z umiarkowanymi bodźcami radiacyjnymi, brakiem parności dużymi kontrastami termicznymi i brakiem opadów, ale ze stresem zimna (0_2C0_10x). Stwierdzono, że opisany powyżej układ warunków pogodowych wstąpił w Słubicach, Toruniu i Poznaniu. Warto także nadmienić, że na analizowa- 
nym obszarze z częstością od 2,9\% w Poznaniu do 1,4\% w Gorzowie Wielkopolskim występuje typ pogody gorącej, z silnymi bodźcami radiacyjnymi, z termofizjologicznym stresem gorąca albo warunkami termoneutralnymi bez parności, z dużymi kontrastami termicznymi i bez opadu (2_3H0_10x, 2_3T0_10x).

W kolejnym etapie pracy określono sezonową zmienność typów, podtypów i klas pogody. Stwierdzono, że podczas zimy występuje najmniejsze (od 20 do 22) zróżnicowanie warunków pogodowych, a wśród określonych typów pogody znajdują się: typ zimny, chłodny i komfortowy a sporadycznie bardzo zimny i ciepły - rycina 2. Typ pogody zimnej, z opadem $\left(-2 \_1 C 0 \_01 x\right)$ lub bez opadu $\left(-2 \_1 C 0 \_00 x\right)$ jest dominujący i stanowi około 60\%, a w Zielonej Górze nawet $65 \%$, wszystkich przypadków warunków pogodowych podczas zimy. Stwierdzono, że w grudniu te dwa typy pogody zimnej, w Gorzowie Wielkopolskim i Zielonej Górze występują w ponad 70\% dni. Należy jednak także podkreślić, że typ pogody zimnej bez opadu występuje z nieco większą częstością niż typ pogody zimnej z opadem, zwłaszcza we wschodniej części analizowanego obszaru, a największe różnice widoczne są w Kole (20\%) oraz w Toruniu (15,8\%) i w Poznaniu (13,7\%). Najmniejsze natomiast zróżnicowanie stwierdzono w Słubicach gdzie typ pogody zimnej bez opadu stanowi 29,5\%, a z opadem 23,5\% przypadków dni zimą.

Wiosną, przekrój występujących typów pogody, w latach 1971-2006, jest bardzo szeroki i sięga od pogody zimnej do bardzo gorącej, co przekłada się na dużą różnorodność warunków pogodowych - rycina 2. Najwięcej (86) kombinacji typów, podtypów i klas pogody występuje w Słubicach, Gorzowie Wlkp. i Kole, a najmniej w Poznaniu (78). Na większości analizowanego obszaru (za wyjątkiem Poznania i Koła) w pierwszej kolejności (24-30\%) w kształtowaniu warunków pogodowych zaznacza się udział typu pogody chłodnej, ze słabymi bodźcami radiacyjnymi, stresem zimna, bez parności, z dużymi kontrastami termicznymi bez opadu $\left(-1 \_1 C 0 \_10 \mathrm{x}\right)$ albo z małymi kontrastami termicznymi z opadem lub bez opadu $\left(-1 \_1 \mathrm{C} 0 \_01 \mathrm{x},-1 \mathrm{C} 0 \_00 \mathrm{x}\right)$. W Poznaniu natomiast określono, że przed typem pogody chłodnej opisanym powyżej, występuje typ pogody komfortowej (0_2C0_10x) z częstością 9\%, w Kole natomiast typ pogody zimnej (-2_1C0_00x) z częstością 8\%. Należy też zaznaczyć, że wiosną w Słubicach zdecydowanie rzadziej występują warunki pogodowe związane z typem pogody zimnej, z kolei w Zielonej Górze pogoda zimna występuje w drugiej kolejności po typie pogody chłodnej.

Lato jest porą roku o największej (od 90 Gorzów Wlkp. i Poznań do 104 Koło) różnorodności stanów pogody na analizowanym obszarze gdzie tylko pierwszy, najczęściej występujący układ warunków pogodowych przekracza nieznacznie próg 10\%, i to nie we wszystkich miejscowościach (Gorzów Wlkp. i Leszno) - rycina 3.

Ryc. 2. Najczęściej występujące rodzaje pogody w Polsce środkowo-zachodniej zimą (XII-II) i wiosną (III-V). Lata 1971-2006

The most frequent types of weather in central-west Poland in winter (December-February) and spring (March-May); 1971-2006

Opracowanie własne, podobnie kolejne ryciny. / Author's own elaboration, as well as other figures. 

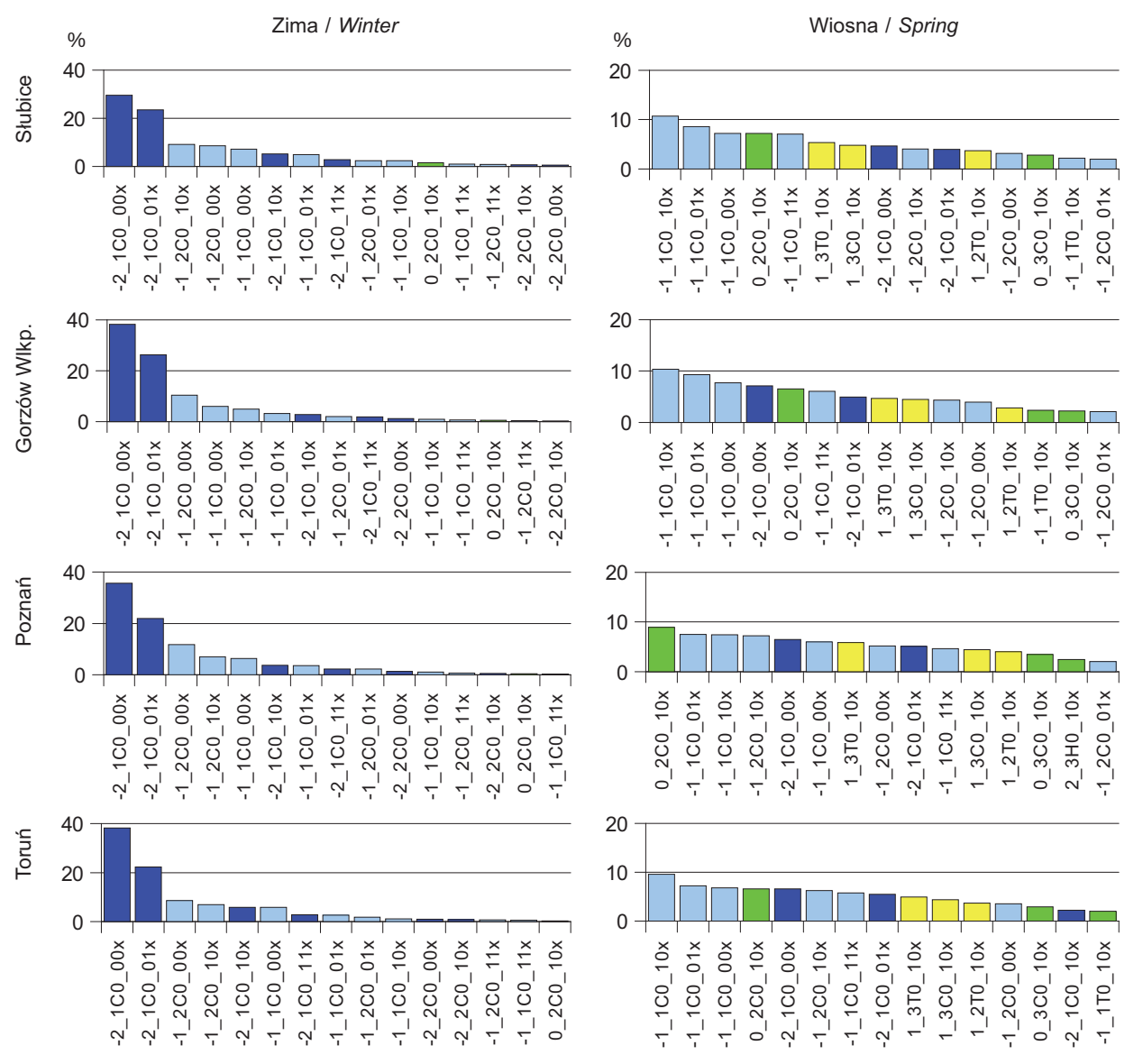

즘 증

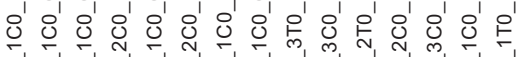

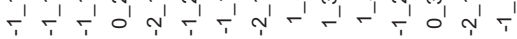
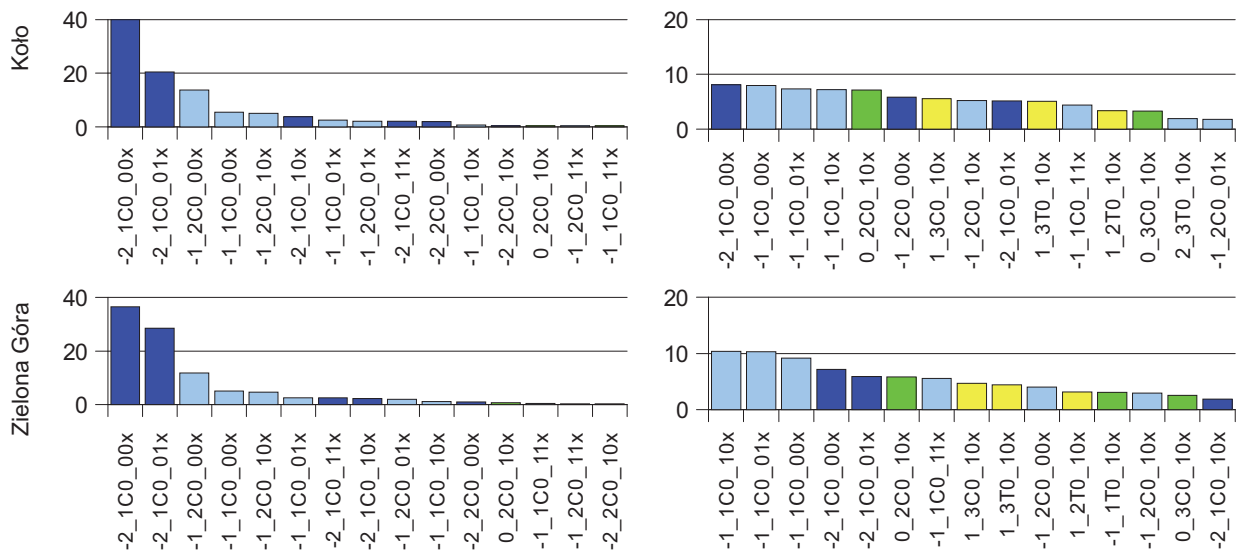

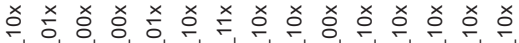

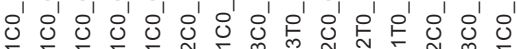

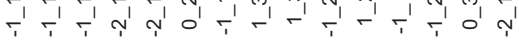
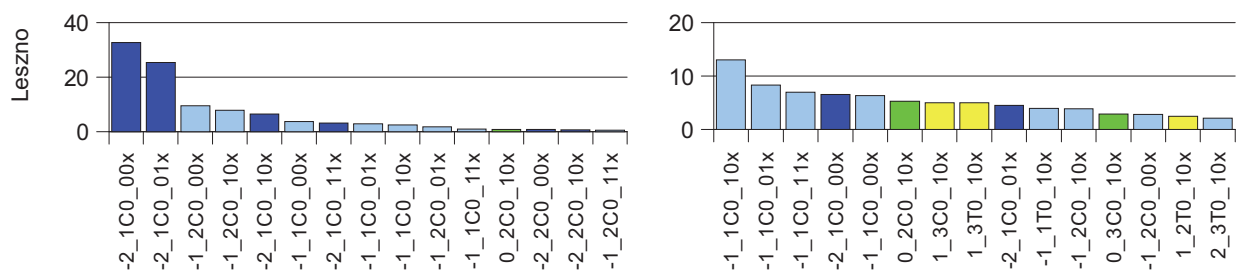

Typ pogody / Weather type:

-2 (zimno / cold)

-1 (chłodno / cool)

0 (komfortowo / comfort)

1 (ciepło / warm) 
Znaczna część analizowanego obszaru wyróżnia się występowaniem na pierwszym miejscu pogody ciepłej z umiarkowanymi bodźcami radiacyjnymi, z brakiem stresu termofizjologicznego, bez parności i bez opadów, ale z dużymi kontrastami termicznymi (1_2T0_10x), wyjątkiem są obszary reprezentowane przez Gorzów Wlkp. i Zieloną Górę - pogoda chłodna ze słabymi bodźcami radiacyjnymi, stresem zimna, brakiem parności, małymi kontrastami termicznymi i z opadem atmosferycznym (-1_1C0_01x). Co więcej, w tych miejscowościach i jeszcze w Lesznie pogoda chłodna pojawia się częściej niż ciepła w czerwcu, a w lipcu i w sierpniu częściej już tylko w Zielonej Górze. W Gorzowie Wlkp. natomiast w sierpniu, pogoda chłodna występuje z taką samą częstością jak pogoda gorąca. Na podstawie uzyskanych wyników stwierdzono także, że w Słubicach pogoda bardzo gorąca (3_3H1_10x), a w Toruniu i Poznaniu - gorąca (2_3H0_10x) zajmują trzecie miejsce jeśli chodzi o kształtowanie warunków pogodowych latem.

Jesienią, podobnie jak wiosną, można spodziewać się wystąpienia wszystkich typów pogody (ryc. 3). W analizowanym wieloleciu (1971-2006) określono od 70 (Toruń) do 85 (Słubice) różnych warunków pogodowych, na układ których składa się kombinacja typów, podtypów i klas. Decydującą rolę w kształtowaniu warunków pogodowych odgrywają typy pogody chłodnej $\left(-1 \_1 \mathrm{C} 0 \_00 \mathrm{x},-1 \_1 \mathrm{C} 0 \_01 \mathrm{x}\right.$, $\left.-1 \_1 \mathrm{C} 0 \_10 \mathrm{x},-1 \_2 \mathrm{C} 0 \_00 \mathrm{x}\right)$ i zimnej $\left(-2 \_1 \mathrm{C} 0 \_00 \mathrm{x},-2 \_1 \mathrm{C} 0 \_01 \mathrm{x}\right)$ stanowiące w sumie od 57,6\% w Zielonej Górze do 32\% w Słubicach wszystkich przypadków jesienią. Typ pogody chłodnej, częściej bez opadu niż z opadem, obserwowany jest jako najczęstszy w północno-zachodniej części regionu (Gorzów Wlkp., Słubice, Zielona Góra, Leszno). Istotne znaczenie dla warunków pogodowych jesienią w Polsce środkowo-zachodniej ma także udział pogody komfortowej i ciepłej.

$\mathrm{Na}$ podstawie biotermiczno-meterologicznej klasyfikacji pogody, w analizowanych latach 1971-2006, obliczono średnie dekadowe wartości wskaźnika przydatności pogody $\left(W E I_{\text {avg }}\right.$ ) do wybranych form rekreacji (ryc. 4). Stwierdzono, że w układzie rocznym występują dwa okresy o najkorzystniejszych warunkach do kąpieli słonecznych (SB), kąpieli powietrznych (AB) i umiarkowanej rekreacji (MR), przypadające na wiosnę i jesień; w sezonie letnim i zimowym następuje pogorszenie warunków. W przypadku intensywnej aktywności (AR) korzystne warunki występują przez cały rok z maksimum od początku jesieni przez okres zimy do połowy wiosny. Uzyskane wyniki znajduja potwierdzenie w literaturze w pracach M. Kuchcik i innych (2013) czy K. Błażejczyka i A. Kunert (2011).

Jeśli chodzi o kąpiele słoneczne (SB), pogoda korzystna najwcześniej rozpoczyna się w Poznaniu - od drugiej dekady kwietnia, następnie w Kole, Toruniu i w Słubicach - od trzeciej dekady kwietnia, a najpóźniej w Gorzowie Wlkp., Zielonej Górze i Lesznie (ryc. 4). Na całym analizowanym obszarze obserwuje

Ryc. 3. Najczęściej występujące rodzaje pogody w Polsce środkowo-zachodniej latem (VI-VIII) i jesienią (IX-XI). Lata 1971-2006

The most frequent types of weather in central-west Poland in summer (June-August) and autumn (September-December); 1971-2006 

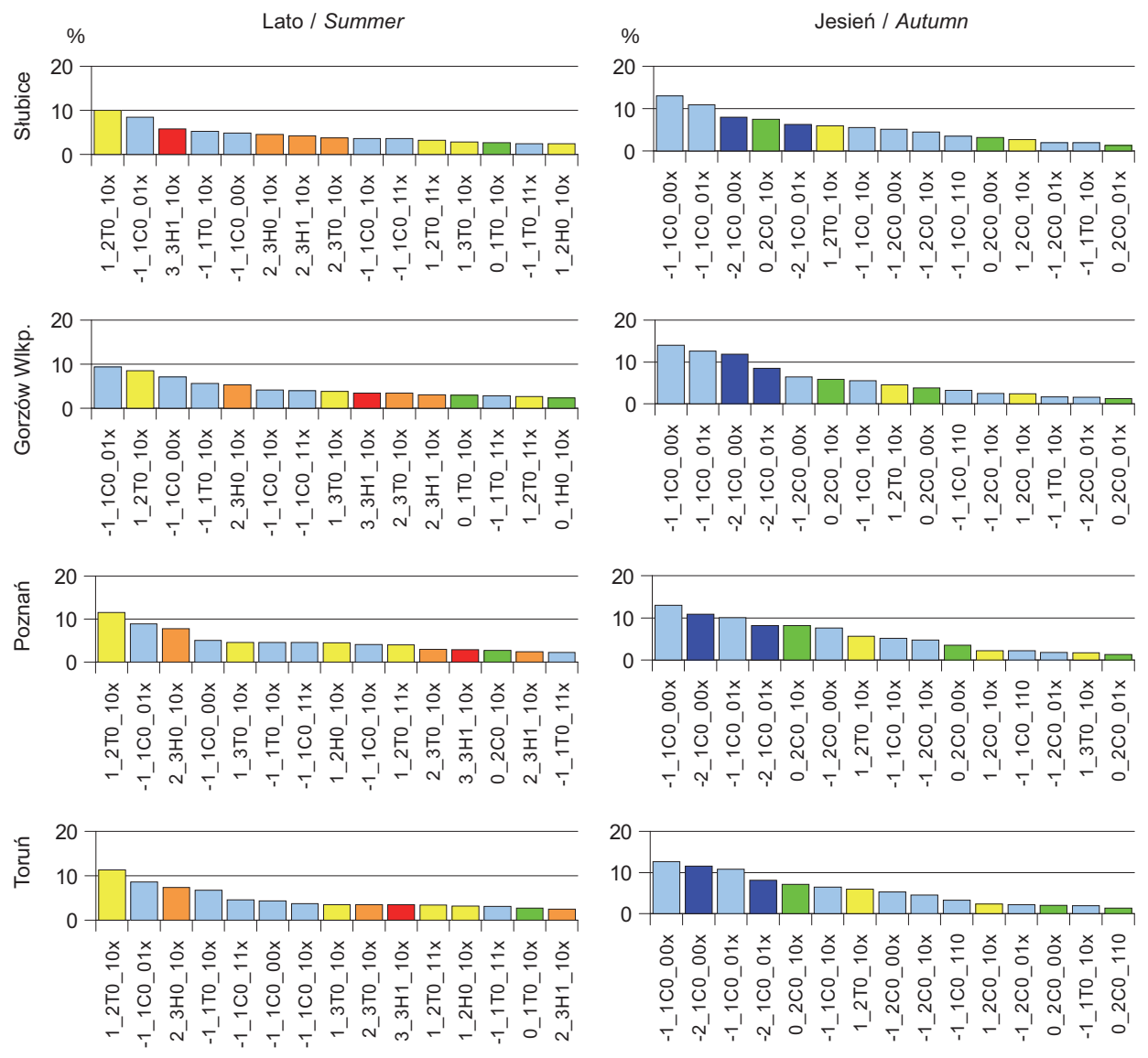

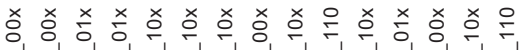

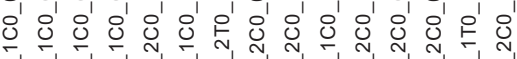

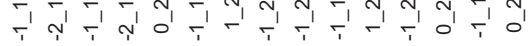
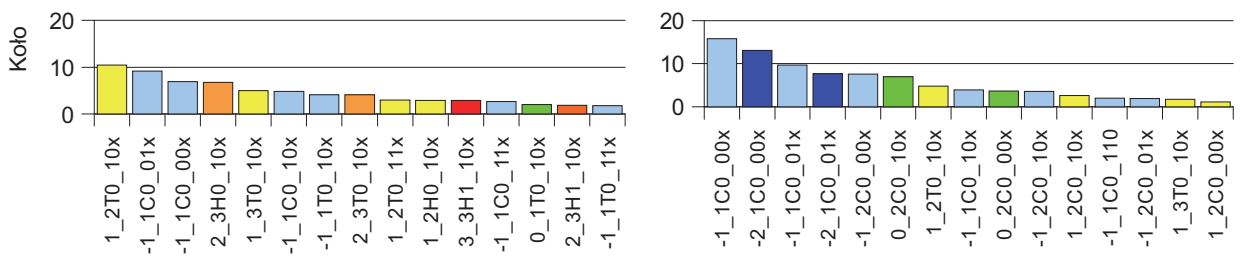

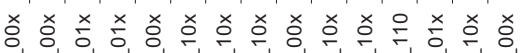

O' O'

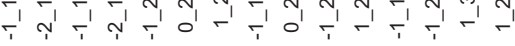
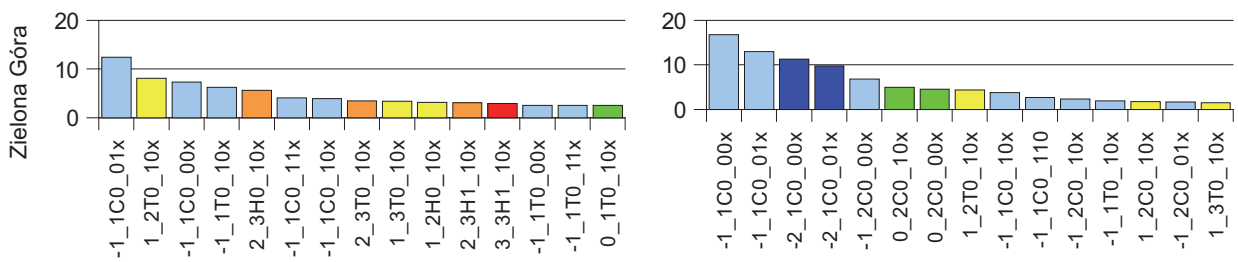

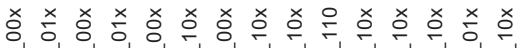
O O O O 1
1
1
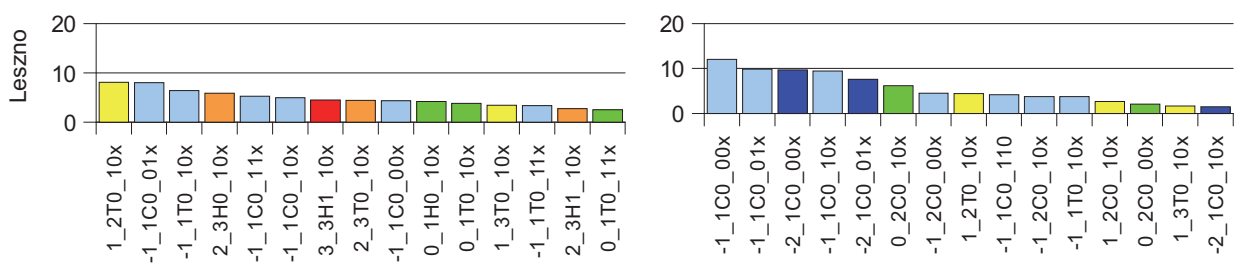

Typ pogody / Weather type:

-2 (zimno / cold)

-1 (chłodno / cool)

0 (komfortowo / comfort)

1 (ciepło / warm)

2 (gorąco / hot)

3 (bardzo gorąco / very hot) 

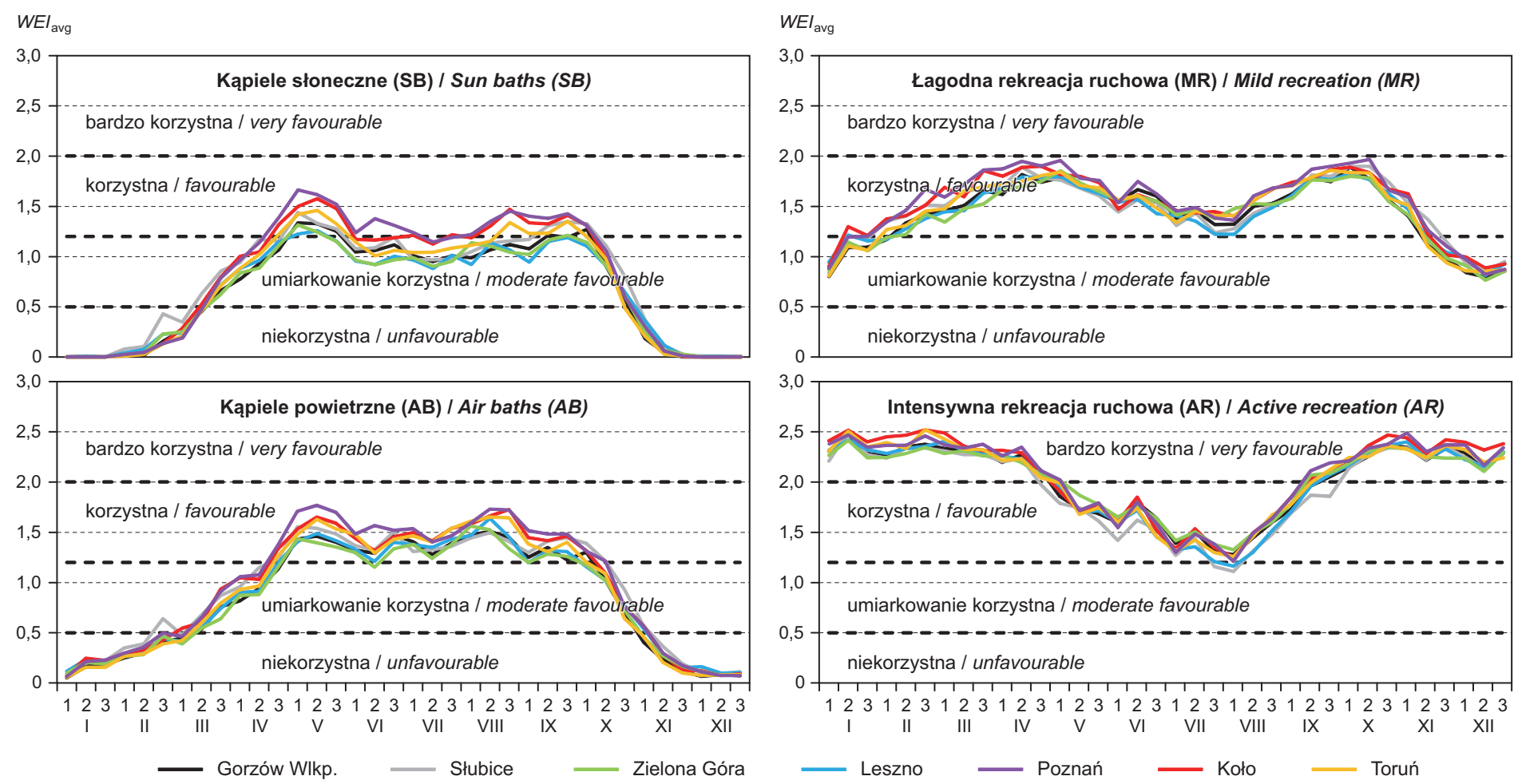

Ryc. 4. Przebieg roczny średnich dekadowych wartości wskaźników oceny pogody $\left(W E I_{\text {avg }}\right.$ ) dla różnych form rekreacji w Polsce środkowo-zachodniej. Lata 1971-2006

Annual course of mean 10 days weather suitability index for various forms of recreation in central-western Poland; 1971-2006 
Tabela 3. Ogólna i skumulowana częstość (\%) występowania rodzajów pogody w Polsce środkowo-zachodniej, wartości średnie roczne za lata 1971-2006 Overall and cumulative frequency (\%) of weather type occurrence in central-west Poland, mean yearly values for the period 1971-2006

\begin{tabular}{|c|c|c|c|c|c|c|c|c|c|c|c|c|c|c|c|c|c|c|c|c|c|}
\hline \multirow{3}{*}{ Lp. } & \multicolumn{3}{|c|}{ Słubice } & \multicolumn{3}{|c|}{ Gorzów Wlkp. } & \multicolumn{3}{|c|}{ Toruń } & \multicolumn{3}{|c|}{ Poznań } & \multicolumn{3}{|c|}{ Koło } & \multicolumn{3}{|c|}{ Zielona Góra } & \multicolumn{3}{|c|}{ Leszno } \\
\hline & \multirow{2}{*}{ 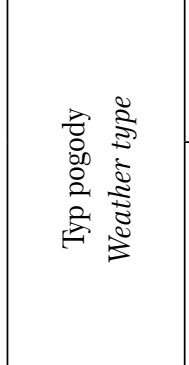 } & \multicolumn{2}{|c|}{$\begin{array}{c}\text { Częstość } \\
\text { Freguency } \\
\%\end{array}$} & \multirow{2}{*}{ 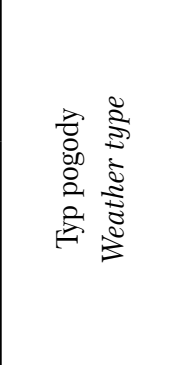 } & \multicolumn{2}{|c|}{$\begin{array}{c}\text { Częstość } \\
\text { Freguency } \\
\%\end{array}$} & \multirow{2}{*}{ 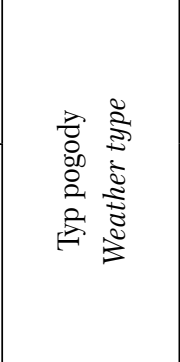 } & \multicolumn{2}{|c|}{$\begin{array}{c}\text { Częstość } \\
\text { Freguency } \\
\%\end{array}$} & \multirow{2}{*}{ 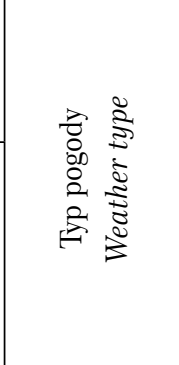 } & \multicolumn{2}{|c|}{$\begin{array}{c}\text { Częstość } \\
\text { Freguency } \\
\%\end{array}$} & \multirow{2}{*}{ 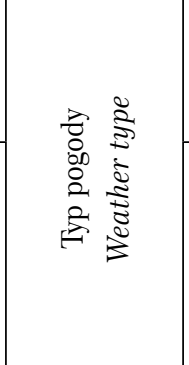 } & \multicolumn{2}{|c|}{$\begin{array}{c}\text { Częstość } \\
\text { Freguency } \\
\%\end{array}$} & \multirow{2}{*}{ 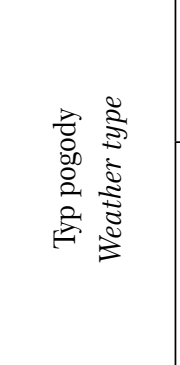 } & \multicolumn{2}{|c|}{$\begin{array}{c}\text { Częstość } \\
\text { Freguency } \\
\%\end{array}$} & \multirow{2}{*}{ 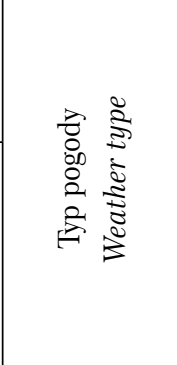 } & \multicolumn{2}{|c|}{$\begin{array}{c}\text { Częstość } \\
\text { Freguency } \\
\%\end{array}$} \\
\hline & & 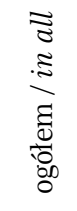 & 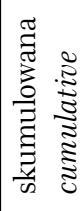 & & 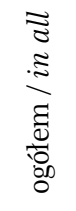 & 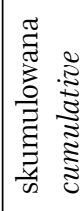 & & 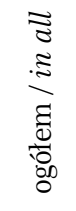 & 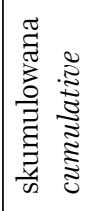 & & 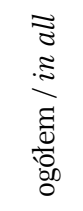 & 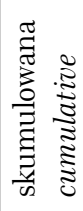 & & 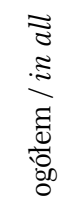 & 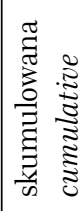 & & 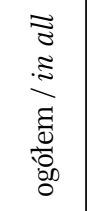 & 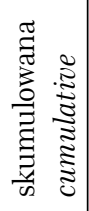 & & 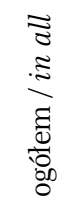 & 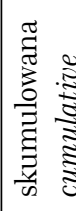 \\
\hline 1 & $-2 \_1 C 0 \_00 x$ & 10,5 & 10,5 & _1C0_00x & 14,2 & 14,2 & $-2 \_1 \mathrm{C} 0 \_00 \mathrm{x}$ & 13,8 & 13,8 & $-2 \_1 \mathrm{C} 0 \_00 \mathrm{x}$ & 13,2 & 13,2 & $-2 \_1 \mathrm{C} 0 \_00 \mathrm{x}$ & 15,2 & 15,2 & $-2 \_1 C 0 \_00 x$ & 13,7 & 13,7 & -2_1C0_00x & 12,1 & 12,1 \\
\hline 2 & $-2 \_1 C 0 \_01 x$ & 8,4 & 18,8 & _1C0_01x & 9 & 24,1 & 2_1C0_01x & 8,9 & 22,7 & $-2 \_1 C 0 \_01 x$ & 8,7 & 21,9 & $-1 \_1 C 0 \_00 x$ & 9,1 & 24,3 & $-2 \_1 \mathrm{C} 0 \_01 \mathrm{x}$ & 10,9 & 24,6 & $-2 \_1 C 0 \_01 x$ & 9,3 & 21,4 \\
\hline 3 & $-1 \_1 C 0 \_01 x$ & 8,2 & 27,1 & 1_1C0_00x & 8,7 & 32 & $-1 \_1 C 0 \_00 x$ & 7,4 & 30,1 & $-1 \_1 C 0 \_00 x$ & 7 & 29,5 & $-2 \_1 \mathrm{C} 0 \_01 \mathrm{x}$ & 8,3 & 32,5 & $-1 \_1 \mathrm{C} 0 \_00 \mathrm{x}$ & 9,6 & 34,2 & $-1 \_1 C 0 \_10 x$ & 7,5 & 28,9 \\
\hline 4 & $-1 \_1 \mathrm{C} 0 \_00 \mathrm{x}$ & 8,1 & 35,1 & 1_1C0_01x & 8,6 & 41,4 & $-1 \_1 C 0 \_01 x$ & 7,3 & 37,4 & $-1 \_1 C 0 \_01 x$ & 7,5 & 37,0 & $-1 \_1 C 0 \_01 x$ & 7,2 & 39,7 & $-1 \_1 C 0 \_01 x$ & 9,6 & 43,8 & $-1 \_1 C 0 \_01 x$ & 7,3 & 36,2 \\
\hline 5 & $-1 \_1 \mathrm{C} 0 \_10 \mathrm{x}$ & 5,6 & 40,7 & 1_1C0_10x & 5,3 & 46,7 & 1_2T0_10x & 5,2 & 42,6 & $-1 \_2 \mathrm{C} 0 \_00 \mathrm{x}$ & 6,1 & 43,1 & $-1 \_2 \mathrm{C} 0 \_00 \mathrm{x}$ & 6,8 & 46,5 & $-1 \_2 \mathrm{C} 0 \_00 \mathrm{x}$ & 5,6 & 49,4 & $-1 \_1 C 0 \_00 x$ & 6,6 & 42,8 \\
\hline 6 & 1_2T0_10x & 5,0 & 45,6 & $-1 \_2 \mathrm{C} 0 \_00 \mathrm{x}$ & & & $-1 \_1 C 0 \_10 x$ & 5,2 & & 1_2T0_10x & & & 1_2T0_10x & & & $-1 \_1 C 0 \_10 x$ & & & & & 2 \\
\hline 7 & $-1 \_2 \mathrm{C} 0 \_10 \mathrm{x}$ & 4,4 & 50,0 & 1_2T0_10x & 4,0 & 55,8 & $-1 \_2 \mathrm{C} 0 \_10 \mathrm{x}$ & 4,4 & 52,2 & 0_2C0_10x & 5,1 & 53,5 & $-1 \_1 C 0 \_10 x$ & 4,2 & 55,3 & 1_2T0_10x & 3,9 & 58,1 & -1_2C0_00x & 4,2 & 51,3 \\
\hline 8 & 0_2C0_10x & 4,3 & 54,3 & $0 \_2 \mathrm{C} 0 \_10 \mathrm{x}$ & 3,6 & 59,4 & $-1 \_2 \mathrm{C} 0 \_00 \mathrm{x}$ & 4,3 & 56,5 & $-1 \_2 \mathrm{C} 0 \_10 \mathrm{x}$ & 4,8 & 58,3 & 0_2C0_10x & 4,1 & 59,4 & $-1 \_1 C 0 \_11 \mathrm{x}$ & 3,2 & 61,3 & $-1 \_2 \mathrm{C} 0 \_10 \mathrm{x}$ & 3,9 & 55,2 \\
\hline 9 & $-1 \_2 \mathrm{C} 0 \_00 \mathrm{x}$ & 4,2 & 58,5 & 1_1C0_11x & 3,5 & 62,9 & 0_2C0_10x & 3,8 & 60,2 & $-1 \_1 \mathrm{C} 0 \_10 \mathrm{x}$ & & 62,7 & $-1 \_2 \mathrm{C} 0 \_10 \mathrm{x}$ & 3,4 & 62,8 & 0_2C0_10x & 3,2 & & 1_2T0_10x & 3,7 & 59,0 \\
\hline 10 & $-1 \_1 C 0 \_11 x$ & 3,8 & 62,3 & $-1 \_2 \mathrm{C} 0 \_10 \mathrm{x}$ & 2,9 & 65,8 & $-1 \_1 C 0 \_11 x$ & 3,5 & 63,8 & 1_3T0_10x & 3,0 & 65,8 & 1_3T0_10x & 3,0 & 65,8 & $-1 \_1 \mathrm{~T} 0 \_10 \mathrm{x}$ & 2,8 & 67,2 & -1_1T0_10x & 3,5 & 62,5 \\
\hline 11 & $-1 \_1 \mathrm{~T} 0 \_10 \mathrm{x}$ & 2,4 & 64,6 & 1_3T0_10x & 2,4 & 68,3 & $-1 \_1 \mathrm{~T} 0 \_10 \mathrm{x}$ & 2,7 & 66,4 & $-1 \_1 \mathrm{C} 0 \_11 \mathrm{x}$ & 2,9 & 68,7 & $-1 \_1 C 0 \_11 x$ & 2,4 & 68,2 & $-1 \_2 \mathrm{C} 0 \_10 \mathrm{x}$ & 2,5 & 69,7 & 0_2C0_10x & 3,3 & 65,8 \\
\hline 12 & 1_3T0_10x & 2,3 & 66,9 & $-1 \_1 \mathrm{~T} 0 \_10 \mathrm{x}$ & 2,4 & & 2_3H0_10x & 2,5 & 68,9 & 2_3H0_10x & & 71,5 & 2_3H0_10x & 2,3 & 70,5 & 1_3T0_10x & 2,3 & 72,0 & $1 \_3$ & 2,5 & 68,4 \\
\hline 13 & $-2 \_1 \mathrm{C} 0 \_10 \mathrm{x}$ & 1,9 & 68,9 & 2_3H0_10x & 1,9 & 72,6 & 1_3T0_10x & 2,4 & 71,3 & $-1 \_1 T 0 \_10 x$ & 1,6 & 73,1 & $1 \_3 \mathrm{C} 0 \_10 \mathrm{x}$ & 1,9 & 72,3 & 2_3H0_10x & 1,9 & 74,0 & $0 \_10 x$ & 2,5 & 70,8 \\
\hline 14 & 2_3H0_10x & 1,8 & 70,7 & 0_2C0_00x & 1,5 & 74,1 & $-2 \_1 \mathrm{C} 0 \_10 \mathrm{x}$ & 2,3 & 73,6 & $-2 \_1 \mathrm{C} 0 \_10 \mathrm{x}$ & 1,6 & 74,7 & 2_3T0_10x & 1,7 & 74,1 & 0_2C0_00x & 1,7 & 75,7 & 2_3H0_10x & 2,2 & 73,0 \\
\hline 15 & 3_3H1_10x & 1,7 & 72,4 & $-1 \_2 \mathrm{C} 0 \_01 \mathrm{x}$ & & 75,5 & 2_3T0_10x & 1,5 & 75,1 & $-1 \_2 \mathrm{C} 0 \_01 \mathrm{x}$ & & 76,2 & 0_2C0_00x & 1,6 & 75,7 & 2_3T0_10x & 1,4 & & $2 \_3$ & 1,9 & 1,0 \\
\hline 16 & 2_3T0_10x & 1,6 & 74,0 & 2_3T0_10x & 1,4 & 76,9 & $-1 \_2 \mathrm{C} 0 \_01 \mathrm{x}$ & 1,3 & 76,4 & 0_2C0_00x & & 77,7 & $-1 \_1 \mathrm{~T} 0 \_10 \mathrm{x}$ & 1,5 & 77,2 & 1_3C0_10x & 1,4 & 78,5 & 1_3C0_10x & 1,7 & 76,7 \\
\hline 17 & $-1 \_2 \mathrm{C} 0 \_01 \mathrm{x}$ & 1,6 & 75,6 & $-2 \_1 \mathrm{C} 0 \_10 \mathrm{x}$ & 1,3 & 78,2 & 1_3C0_10x & 1,3 & 77,7 & 1_2T0_11x & 1,5 & 79,2 & $-2 \_1 \mathrm{C} 0 \_10 \mathrm{x}$ & 1,5 & 78,7 & $-1 \_2 \mathrm{C} 0 \_01 \mathrm{x}$ & 1,4 & 79,9 & $-1 \_1 \mathrm{~T} 0 \_11 \mathrm{x}$ & 1,4 & 78,1 \\
\hline 18 & 1_3C0_10x & 1,4 & 77,0 & $1 \_3 \mathrm{C} 0 \_10 \mathrm{x}$ & & 79,6 & 1_2T0_11x & 1,3 & 79,0 & 1_3C0_10x & & 80,6 & $-1 \_2 \mathrm{C} 0 \_01 \mathrm{x}$ & 1,5 & 80,2 & $-2 \_1 \mathrm{C} 0 \_10 \mathrm{x}$ & 1,1 & 81,0 & $-2 \_1 C 0 \_11 x$ & 1,3 & 79,4 \\
\hline 19 & 2_3H1_10x & 1,4 & 78,4 & $-1 \_1 T 0 \_11 x$ & 1,2 & 80,7 & 1_2H0_10x & 1,2 & 80,1 & 1_2H0_10x & 1,4 & 82,0 & 1_2C0_10x & 1,3 & 81,5 & $-2 \_1 \mathrm{C} 0 \_11 \mathrm{x}$ & 1,0 & 82,1 & 3_3H1_10x & 1,2 & 80,6 \\
\hline 20 & 1_2T0_11x & 1,3 & 79,7 & 1_2C0_10x & 1,0 & 81,8 & -1_1T0_11x & 1,1 & 81,3 & 2_3T0_10x & 1,2 & 83,2 & 1_2T0_11x & 1,2 & 82,7 & 1_2H0_10x & 1,0 & 83,1 & 0_1H0_10x & 1,2 & 81,8 \\
\hline 21 & 0_2C0_00x & 1,3 & 81,0 & 1_2T0_11x & 1,0 & 82,8 & $-2 \_1 C 0 \_11 x$ & 1,0 & 82,3 & 1_2C0_10x & 1,0 & 84,2 & 1_2H0_10x & 1,0 & 83,7 & $-1 \_1 \mathrm{~T} 0 \_11 \mathrm{x}$ & 1,0 & 84,0 & 0_1T0_10x & 1,1 & 82,9 \\
\hline 22 & 1_2C0_10x & 1,3 & 82,3 & 3_3H1_10x & 0,9 & 83,7 & 0_2C0_11x & 1,0 & 83,3 & $-2 \_1 C 0 \_11 x$ & 1,0 & 85,2 & 0_3C0_10x & 0,9 & 84,6 & 2_3H1_10x & 0,9 & 84,9 & 1_2C0_10x & 1,1 & 84,0 \\
\hline 23 & $-1 \_1 \mathrm{~T} 0 \_11 \mathrm{x}$ & 1,1 & 83,4 & 2_3H1_10x & 0,9 & 84,6 & 1_2C0_10x & 1,0 & 84,2 & 0_2C0_11x & 1,0 & 86,2 & $-2 \_1 \mathrm{C} 0 \_11 \mathrm{x}$ & 0,8 & 85,3 & 1_2C0_10x & 0,8 & 85,8 & $-1 \_2 \mathrm{C} 0 \_01 \mathrm{x}$ & 1,1 & 85,1 \\
\hline 24 & $-2 \_1 \mathrm{C} 0 \_11 \mathrm{x}$ & 1,0 & 84,4 & $-2 \_1 C 0 \_11 x$ & 0,8 & 85,4 & 3_3H1_10x & 0,9 & 85,2 & 0_3C0_10x & 1,0 & 87,1 & 3_3H1_10x & 0,8 & 86,1 & $-1 \_1 \mathrm{~T} 0 \_00 \mathrm{x}$ & 0,8 & 86,6 & 0_2C0_00x & 1,0 & 86,0 \\
\hline 25 & 1_2H0_10x & 0,8 & 85,2 & 0_1T0_10x & 0,8 & 86,2 & 0_2C0_00x & 0,9 & 86,1 & $-1 \_1 \mathrm{~T} 0 \_11 \mathrm{x}$ & 0,8 & 87,9 & $0 \_2 \mathrm{C} 0 \_11 \mathrm{x}$ & 0,7 & 86,8 & 3_3H1_10x & 0,8 & 87,4 & 1_2T0_11x & 0,8 & 86,8 \\
\hline
\end{tabular}

Opracowanie własne / Author's own elaboration. 
się charakterystyczne obniżenie przydatności warunków pogodowych do kąpieli słonecznych od pierwszej dekady czerwca do końca pierwszej dekady sierpnia w okolicach Poznania i Koła, nieco dłużej w Toruniu - do drugiej dekady sierpnia i najdłużej - do drugiej dekady września w Słubicach i Gorzowie Wlkp.. Należy tutaj zaznaczyć, że najkorzystniejsze warunki do kąpieli słonecznych $\mathrm{w}$ analizowanych latach występują w Poznaniu, gdzie pomimo widocznego spadku wartości wskaźnika $W E I_{\text {avg }}$ w okresie letnim, pozostają one zaklasyfikowane nadal jako warunki korzystne, z wyjątkiem drugiej dekady lipca. Nieznacznie mniej korzystnie niż w Poznaniu prezentują się także warunki do kąpieli słonecznych w Kole. Obszar Pojezierza Poznańskiego oraz Kotliny Kolskiej wyróżnia się sumą godzin z usłonecznieniem rzeczywistym szczególnie w okresie wiosny i lata (Koźmiński i Michalska, 2001). Najgorzej wypada obszar reprezentowany przez Zieloną Górę i Leszno, gdzie pomimo jesiennego wzrostu wartości $W E I_{\text {avg }}$ warunki do kąpieli słonecznych określić można jedynie jako umiarkowanie korzystne. Według danych Atlasu klimatu Polski (2005) obszar ten odznacza się zdecydowanie częstszym występowaniem dni pochmurnych, szczególnie wiosną. Warunki nieprzydatne do kąpieli słonecznych stwierdzono tu od połowy trzeciej dekady października do drugiej dekady marca, jedynie w Słubicach nieco krócej - od pierwszej dekady listopada do pierwszej dekady marca.

Analiza warunków pogodowych z punktu widzenia kąpieli powietrznych (AB) wykazała, że pomimo wahań wartości wskaźnika $W E I_{\text {avg }}$, od początku trzeciej dekady kwietnia do pierwszej dekady października na większości analizowanego obszaru, a w Poznaniu i Słubicach do drugiej dekady października, występują warunki korzystne (ryc. 4). Okres z warunkami niekorzystnymi do kąpieli powietrznych, podobnie jak dla kąpieli słonecznych, rozpoczyna się na początku listopada i kończy w pierwszej dekadzie marca.

Do form rekreacji związanych z umiarkowaną aktywnością (MR) występowały głównie korzystne warunki pogodowe - przez 74\% dni roku, z charakterystycznym maksimum wartości wskaźnika $W E I_{\text {avg }}$ wiosną w kwietniu i jesienią w październiku. Okres kiedy warunki pogodowe są umiarkowanie korzystne jest dość krótki i trwa przeciętnie od drugiej dekady listopada do drugiej dekady stycznia w Poznaniu, Kole i Lesznie lub do pierwszej dekady lutego na pozostałym obszarze (ryc. 4).

W ciągu roku występują korzystne lub bardzo korzystne warunki pogodowe do intensywnej aktywności rekreacyjnej (AR), związanej na przykład z bieganiem, jazdą na rowerze czy grą w tenisa lub siatkówkę (ryc. 4). Jedynie w trzeciej dekadzie lipca i pierwszej dekadzie sierpnia w Słubicach i Lesznie stwierdzono warunki umiarkowanie korzystne związane z najwyższą temperaturą i większą możliwością pojawienia się stresu gorąca, prowadzącym do zwiększonego obciążenia organizmu procesami termoregulacyjnymi. Okres pogody najbardziej odpowiedniej do tej formy rekreacji, w przeciwieństwie do opisanych powyżej, przypada od drugiej dekady września do pierwszej dekady maja. Wiąże się to 
z faktem rekompensaty niedoboru ciepła z otoczenia i bodźców radiacyjnych przez metaboliczną produkcję ciepła (Kuchcik i inni, 2013).

\section{Podsumowanie}

W analizowanym wieloleciu 1971-2006 w Polsce środkowo-zachodniej wystąpiło od 112 (Gorzów Wlkp.) do 130 (Słubice, Koło) różnych rodzajów pogody, będących kombinacją jej typów, podtypów i klas. Ze wszystkich wyznaczonych typów pogody, 20 najczęściej występujących decydowało o warunkach pogodowych w ponad 80\% dni w roku, a pierwszych 6-7 w 50\% dni w roku. Na podstawie zastosowanej klasyfikacji biotermiczno-meteorologicznej wykazano prawidłowość sezonową częstości występowania warunków pogodowych. Z przeprowadzonych analiz wynika bowiem, że największą różnorodnością warunków pogodowych odznacza się lato, nieco mniejszą wiosna i jesień, a najmniejszą zima.

Na duże zróżnicowanie warunków pogodowych latem może mieć wpływ dość częste występowanie w tym okresie termofizjologicznego stresu zimna (ponad $20 \%)$ i związanych z nim reakcji dostosowawczych organizmu oraz ponad 70\% udział w miesiącach letnich dni z dużymi kontrastami termicznymi, czy także stosunkowo często pojawiające się silne bodźce radiacyjne, co potwierdzają w swoich pracach K. Błażejczyk (2004, 2005) czy M. Dubicka i S. Sikora (2005).

Wydzielone na odstawie wskaźnika $W E I_{\text {avg }}$ okresy o różnej przydatności warunków pogodowych do wybranych form rekreacji mogą być wykorzystane w planowaniu i optymalnym wykorzystaniu czasu wolnego w terenie otwartym na obszarze Polski środkowo-zachodniej. Wydzielono dwa okresy najbardziej odpowiednie do kąpieli słonecznych: od drugiej dekady kwietnia do pierwszej dekady czerwca oraz od pierwszej dekady sierpnia do końca pierwszej dekady października. Najkorzystniejsze warunki do kąpieli słonecznych występują w Poznaniu, a najgorsze w Zielonej Górze i Leszno, gdzie warunki korzystne stwierdzono tylko w pierwszej i drugiej dekadzie maja. Jeśli chodzi o kąpiele powietrzne, warunki korzystne na większości analizowanego obszaru panują od początku trzeciej dekady kwietnia do pierwszej dekady października, a w Poznaniu i Słubicach do drugiej dekady października. Do form rekreacji związanych z umiarkowaną aktywnością warunki pogodowe są korzystne przez $74 \%$ dni roku z maksimum w kwietniu i w październiku, a do intensywnej aktywności rekreacyjnej - praktycznie przez cały rok.

\section{Piśmiennictwo}

Atlas klimatu Polski, 2005, red. H. Lorenc, IMGW, Warszawa,

BioKlima2.6., pakiet programu, https://www.igipz.pan.pl/Bioklima-zgik.html

Błażejczyk K., 2002, Znaczenie czynników cyrkulacyjnych i lokalnych w kształtowaniu klimatu i bioklimatu aglomeracji warszawskiej, Dokumentacja Geograficzna, 26. 
Błażejczyk K., 2004, Bioklimatyczne uwarunkowania rekreacji i turystyki w Polsce, Prace Geograficzne, IGiPZ PAN, 192, Warszawa.

Błażejczyk K., 2005, Biotermiczno-meteorologiczna klasyfikacja pogody jako narzędzie oceny warunków bioklimatycznych, [w]: Z. Babiński (red.), Środowisko przyrodnicze w badaniach geografii fizycznej, Promotio Geographica Bydgostensia, 2, s. 89-127.

Błażejczyk K., Kunert A., 2011, Bioklimatyczne uwarunkowania rekreacji i turystyki w Polsce, Monografie IGiPZ PAN, 13, Warszawa.

Dubicka M, Sikora S., 2005, Typy pogody we Wroctawiu z punktu widzenia rekreacji i turystyki, Czasopismo Geograficzne, 76, 4, s. 345-365.

Freitas C.R. de, 2001, Theory, concepts and methods In tourism climate research, [w:] A. Matzarakis, C.R. de Freitas (red.), Proceedings of the 1st International Workshop on Climate, Tourism and Recreation, ISB, Commission on Climate, Tourism and Recreation, www.uni-freiburg.de/isb (10.12.2015).

Freitas C.R. de, 2003, Tourism climatology: evaluating environmental information for decision making and business planning in the recreation and tourism sector, International Journal of Biometeorology, 48, s. 45-54.

Kondracki J., 2002, Geografia regionalna Polski, Wydawnictwo Naukowe PWN, Warszawa.

Kozłowska-Szczęsna T., Błażejczyk K., Krawczyk B., 1977, Bioklimatologia człowieka. Metody $i$ ich zastosowanie w badaniach bioklimatu Polski, Monografie IGiPZ PAN, 1, Warszawa.

Koźmiński C., Mąkosza A., Michalska B., 2007, Bioklimatyczne warunki wypoczyn$k u$ w rejonie jeziora Miedwie w pótroczu cieptym, Przegląd Naukowy Inżynieria i Kształtowanie Środowiska, 3 (37).

Koźmiński C., Michalska B., 2008, Ocena warunków pogodowych dla rekreacji i turystyki w rejonie Świnoujścia, [w:] M. Dutkowski (red.), Problemy turystyki i rekreacji, t. 1, US Oficyna IN PLUS, Szczecin, s. 31-42.

Koźmiński C., Michalska B., 2011, Bioklimatyczne uwarunkowania lecznictwa uzdrowiskowego i wypoczynku w rejonie Nałęczowa, Acta Balneologica, 53, 4, s. 300-307.

Koźmiński C., Michalska B., Mąkosza A., 2015, Klimatyczne uwarunkowania dtugości sezonu turystycznego w strefie polskiego wybrzeża Battyku, [w:] Uwarunkowania i plany rozwoju turystyki. Turystyka w badaniach geograficznych, red. A. Młynarczyk, A. Zajadacz, Seria Turystyka i Rekreacja - Studia i Prace, 15, UAM, s. 53-72.

Kuchcik M., Błażejczyk K., Szmyd J., Milewski P., Błażejczyk A., Baranowski J., 2013, Potencjat leczniczy klimatu Polski, Wydawnictwo Akademickie Sedno, Warszawa.

Matzarakis A., 2001, Climate and bioclimate information for tourism in Greece, [w:] A. Matzarakis, C.R. de Freitas (red.), Proceedings of the 1st International Workshop on Climate, Tourism and Recreation, ISB, Commission on Climate, Tourism and Recreation, www.uni-freiburg.de/isb (10.12.2015).

Mąkosza A., 2007, Biotermiczno-meteorologiczna klasyfikacja pogody do oceny warunków bioklimatycznych w sezonie letnim na Nizinie Szczecinskiej, [w:] Materiaty Konferencyjne z I Ogólnopolskiej Konferencji Doktorantów, marzec 2007, Akademia Rolnicza, Kraków, s. 47.

Miszuk B., 2006, Ocena warunków bioklimatycznych obszarów górskich z punktu widzenia turystyki i rekreacji przy wykorzystaniu biotermiczno-meteorologicznej klasyfikacji pogody na przyktadzie danych ze Szrenicy, Annales UMCS, sec. B, 61, 36, s. 308-319.

Miszuk B., 2008, Charakterystyka warunków bioklimatycznych Karkonoszy z punktu widzenia różnych form turystyki i rekreacji, Prace Geograficzne, IGiGP UJ, 120, Kraków, s. 79-91. 
Sikora S., 2008, Bioklimat Wroctawia, Rozprawy Instytutu Geografii i Rozwoju Regionalnego Uniwersytetu Wrocławskiego, 5.

Wereski S., 2012, Przydatność warunków bioklimatycznych do turystyki wypoczynkowej w Solinie (1981-1998), Przegląd Geograficzny, 84, 3, s. 447-456.

[Wpłynęło: styczeń; poprawiono: marzec 2016 r.]

AGNIESZKA MĄKOSZA

\section{BIOMETEOROLOGICAL CLASSIFICATION OF WEATHER CONDITIONS FOR TOURISM AND RECREATION IN CENTRAL-WESTERN POLAND}

The assessment of climatic as well as bioclimatic conditions should consist of the analysis of a set of meteorological elements which provides information on current weather conditions. Such an analysis of weather conditions allows for determination of the influence of the whole set of meteorological elements on the human body, in particular when the bioclimatic indices are calculated on the basis of the human heat balance.

The paper concerns the assessment of weather conditions in central-western Poland in terms of tourism and recreation, made with the use of biothermal-meteorological weather classification including weather types, subtypes and classes. The calculations were made on the basis of meteorological data of second measurement date (12 UTC) in the period 1971-2006. In the analysed period, there were from 112 (Gorzów Wlkp.) to 130 (Słubice, Koło) types of weather recorded. Among all determined weather types, the 20 which were most commonly observed determined the weather conditions on more than $80 \%$ of days in a year. On the basis of the adopted bio-thermal-and-meterorological classification, a seasonal regularity of weather conditions occurrence was shown. The conducted analyses have shown that the highest variety of weather conditions was observed in summer, followed closely by spring and autumn, and the least in winter.

The periods of different suitability for the selected forms of recreations, as identified with the use of WEI index, can be useful for planning and optimal spending of one's leisure time outdoors on the area of central-western Poland.

Two periods most favourable for sunbathing were identified i.e., from the second decade of April to the first decade of June, and from the first decade of August to the end of the first decade of October. The most favourable conditions for air bathing occurred in Poznań, and the worst in Zielona Góra and Leszno, where the favourable conditions were found only in the first and second decade of May.

The analysis of weather conditions showed that in the case of air bathing (AR), the favourable conditions were found from the beginning of the third decade of April to the first decade of October on most of the analysed area, and in Poznań and Słubice till the second decade of October.

As for moderate recreation, favourable weather conditions were identified on $74 \%$ of days in a year with the maximum in April and October. In the case of active reaction, conditions identified on the basis of the index as favourable or very favourable occurred throughout the year. 